International Journal of Human and Health Sciences Vol. 04 No. 01 January'20

Review article:

\title{
The Revolutionary Role of Abulcasis in the History of Surgery
}

Diya Baker ${ }^{l}$,Yusuf Abdallah ${ }^{2}$

\begin{abstract}
$\underline{\text { Abstract }}$
The Islamic golden era was named as such in recognition of the advancement of human knowledge in addition to the efficacy at which it took place. A time which spanned the late $7^{\text {th }}$ century until the early $14^{\text {th }}$ century saw the illumination of medical practices and transmission of the scriptures to Europe. This naturally led to the rise of renaissance science. Arab intelligentsias such as Avicenna and Abulcasis were the driving gears behind this movement.Abulcasis, born in Andalucía in the year $936 \mathrm{AD}$, is renowned for delivering his innovations in a thirty-volume medical and surgical encyclopaedia known as 'Kitab Al Tasrif' which translates to the Book of Concessions. Housed within, are the roots of many modern-day technologies that are still used and a base of knowledge that was beyond his time. In a time where Europe's biggest library held a mere thirty-six volumes, Abulcasis was designing one device after the other. The discrepancy in knowledge between the East and the West was made more apparent when one of Abulcasis' innovations, the vaginal speculum, was not fully understood and one of its parts were erroneously deemed to be for decoration.His excellence in areas of obstetrics and gynaecology, breast surgery, herbal medicine and neurosurgery were made clear throughout his discussions within Kitab Al Tasrif. He was also a keen educator as he strived to encourage the then-tabooed study of anatomy post-mortem.Abulcasis truly had a significant effect on today's medicine and surgery.
\end{abstract}

Keywords: Abulcasis, Kitab Al Tasrif, Book of Concessions, Islamic golden era

International Journal of Human and Health Sciences Vol. 04 No. 01 January'20 Page : 8-14 DOI: http://dx.doi.org/10.31344/ijhhs.v4i1.113

\section{Introduction:}

The Islamic golden era was named as such, not purely because of the advancement of human knowledge that took place but, the manner in which it took place. The golden era illuminated the health practices of the Middle East and transmitted medical scriptures to Europe leading the rise of Renaissance science. Western medicine is currently flourishing. From, harnessing new surgical equipment to the designs of the first hospital a significant portion of medicine is indebted to the prodigious works of the Arab physicians. From the late seventh century until the early fourteenth century ambivalence of scientific procedure and medical information was replaced with accurate and thorough research, as a consequence of significant contributions from intellectuals at this time $e^{1,2}$.
Arab intelligentsi as such as Avicenna, produced numerous repositories of medical knowledge, which had impacts far more widespread geographically than the area of their conception. The most infamous of which was a compilation of 5 books completed in 1025. "Al-Qanun Fi Al Tibb"- Latinised as the "Canon of Medicine"3-5. The Canon of Medicine was designed to be the first medical encyclopaedia that combined the remedial traditions of Galen and thus Hippocrates into the accepted Aristotelian natural philosophy ${ }^{6,7}$. Avicenna used the Canon to explain that he believed diseases had specific causes and stated "cause in medical works, refers to that which initiates a given state of human body, or maintains fixity of such a state" .Such insights to the working of man were unheard of at this time, and was amongst many reasons Avicenna was described as

1. College of Medicine and Dental Sciences, University of Birmingham, UK

2. College of Medicine and Dental Sciences, University of Birmingham, UK

Correspondence to: Diya Baker, College of Medicine and Dental Sciences, University of Birmingham, UK. E-mail:Diya.Baker@nhs.net 
being "ahead of his time" and no doubt cemented his stature in the medical field".

At a similar point Abu Al-Qasim Al-Zahrawi Abulcasis, was innovating in the field of surgery. Amongst the finest works produced in the era, Abulcasis produced a thirty-volume medical and surgicalencyclopaedia labelled "Kitab Al Tasrif" translating as the "Book of Concessions"- his magnum opus. Pioneering surgical equipment hypothesised by Abulcasis in the Book of Concessions has been said to have contributed to two hundred pieces of surgical equipment, many of which are still used ${ }^{10}$. From specula and surgical hooks for gynaecological surgery, to the bone cutter for orthopaedic surgery, the equipment illustrated in Kitab Al Tasrif shaped the future advancement of surgery throughout the following generations ${ }^{10,11}$.

\section{Biography of Abulcasis}

Abulcasis was born in the Andalusian area of Spain, eight kilometres northwest of Córdoba called Al-Zahra, in the year $936 \mathrm{AD}$. Little is known on the early life of Abulcasis as a result of the extensive destruction of libraries that that took place during the Castillian-Andalucian conflicts. What is known, is that the area thrived with scientific fervour and trade ardour ${ }^{2,12}$. Cordoba at the time was considered a haven of intellect and attracted leading artists, scholars and poets. Umayyad rule at the time took advantage of the situation to send scribes and copyists to the learning centres of Alexandria, Damascus and Baghdad to ensure a great quantity of work was translated from the original Latin and Greek. Amongst the works copied included the renowned Paulus, Galen and Hippocrates. Over time, the disparity of advancement between the work of the West and the East was clear. Over half a million volumes of texts were stored in Andalusia in the tenth century in comparison to the largest library in Europe outside of Andalusia, which contained a mere thirty-six volumes ${ }^{2}$.

Andalusia at the time was ruled by the Umayyad Caliphs who prided their legacy on infrastructure and development. Medical improvements took place with the production of many hospitals to treat the poor and diseased and hundreds of public baths as a public health initiative. Hospitals much like those of the National Health Service in the UK were free on point of entry but, Andalusian hospitals went further, by ensuring that even treatment was free and patients under the hospitals care-when discharged- would be supplemented with wealth correlating to the work missed and to be missed on recovery ${ }^{10,12}$.

Libraries were installed under the command of the caliphs and with this the Umayyads cultured a fulfilling learning environment for all. Throughout this time, Abulcasis was duly recognised for his gifted abilities, was assigned as the court physician for the Umayyad caliph Al Hakam II and became royal patron. Abulcasis' generally gained popularity by championing a less maladroit method of scribing patient details, he decided to correctly record treatments for maladies seen and thus begins a primitive form of evidence based medicine. This method of work gave credence to Abulcasis and meant his work Kitab Al Tasrif became the standard source of reference in Islamic and European medicine and was a source of unquestionable enlightenment ${ }^{11}$.

\section{Kitab Al Tasrif}

Completed in $1000 \mathrm{AD}$, its contents influenced the progress of medicine in Europe until the late seventeenth century. Initially the contents were translated to Latin and such was the importance of the work, it rapidly displaced Avicenna's "Canon of Medicine" in European Universities andestablished novel techniques of intervention not previously featured in detail in medieval Europe $^{13}$.

Abulcasis is described as attempting to classify diseases and treatments in Kitab Al Tasrif in order to become the physicians practical guide to medicine. Its meticulous nature encompasses description of theorised pathophysiology of diseases, the signs that are spotted at the time and a hypothesis as to the cause based on these clinical symptoms. Fundamentally, symptom recognition was highlighted as part of the physician's consultation. The examination of patient's vital signs (pulse and breathing rates) and urine components were described and thus began the technique of pairing the history the patient presents to the physician and the examination findings together with a "positive bed side manner" ${ }^{14}$. This practice is still used as common place in clinics presently and forms the bedrock of diagnosis, with majority of patient cases correctly diagnosed on the history alone ${ }^{14,15}$.

Along with the changed bedside manner; ethical and theological considerations at the time were also challenged. The religious conviction of Abulcasis for the Islamic faith meant, that religious wariness to dissection invoked a controversial debate amongst scholars at the time ${ }^{16}$. The doctrine 
International Journal of Human and Health Sciences Vol. 04 No. 01 January'20

surrounding the complex issue of uncertainty as to the religious permissibility of anatomical dissection was deliberated. Scholars would pit the beneficence of the study of anatomy and its intricacies against the autonomy and religious rights of the patients to remain untouched following death. Whilst Abulcasis was a devout Muslim and emphasised his religious convictions, he believed that the study of anatomy was the way to understand Allah's supreme creation and his philosophy towards such was best described by Ibn Rushd, the Muslim philosopher of the twelfth century: "He who engages in science of anatomy, increases his belief in God"17.

With this enthusiasm for anatomy, Abulcasis ensured he compiled medical, dental and pharmaceutical knowledge under thirty treatises; with the final treatise focussing on the art of surgery. The final treatise is considered Abulcasis' era defining work. It was here that he declared the revival of classical Greco-Roman surgery formulated by Hippocrates, Galen and Paulus ${ }^{16-19}$. Abulcasis was systematic in his collection of the Ancient works of these historical figures and began to analyse them with respect to the contemporary knowledge he had gained working as a surgeon. The credibility of his writing was his own personal experiences and he would augment his descriptions with original illustrations of equipment, incisions and treatments. According to Kitab Al Tasrif the study of anatomical structures was a necessity because this would guide the surgeons' hand. Without experience and practice the "consequences would be disastrous", and it was with this mantra Abulcasis' ethical principles influence the students. His advice to those that wished to follow in his surgical shadow, was to be experienced in anatomy before completing the physical practice which guaranteed no malice would be bestowed upon the patient ${ }^{20}$.

Ultimately, Kitab Al Tasrif gained attraction as scripture which not only pushed the ideological and dogmatic thinking of those that disagreed with pursuing the knowledge of the human anatomy but, it did so in a style that was morally approved by religious scholars. It was bold yet considerate of divergent views and ensured that free-thinking debate would not be suppressed. Revolutionary thinking in the theological realm extended to the evidence based medical realm where Abulcasis used his composition to highlight the differences in work from Galen. In central Europe at this same point in time, challenging the work of Galen remained comparable to sacrilege until the arrival of Andreas Vesalius of the sixteenth century. Contrastingly, Abulcasis enveloped in his research fostering environment was undeterred to illustrate the anatomical discrepancies to Galen's work that he had observed ${ }^{21}$.

\section{Breast Surgery}

Kitab Al Tasrif had a multitude of innovative surgical procedures, one example described in some detail is for the management of male breast resembling female - interpreted as gynaecomastia. Gynaecomastia is defined as a benign growth of more than two centimetres of palpable subareolar gland and ductal breast tissue in male chests ${ }^{22}$. The description of breast enlargement in males was first characterised by Galen, who coined the term to apply to it's a typicality.However, no mention was ever found of surgical treatment in the Galenic Era until the Byzantine physician Paulus of Aegina indicated the possible surgical treatment in the Book dubbed "Epitome of Medicine" that he had assembled ${ }^{23}$. Superficially, it appeared that Abulcasis simply then copied the ideas and writings of Paulus in this field and called them his own. On observing more closely, there was clear modification by Abulcasis to the procedure as well as the administered medications. Contrasting with Paulus' description of the procedure, the modified procedure involved the incision of the dermal skin layers to take place in a lunate shape above the breast rather than below ${ }^{24,25}$. This allowed the aiding of removal of more subcutaneous tissue from the male breast and prevent the breast sagging. Additionally, unlike that of his antecedent,Abulcasis would use his vast understanding of herbal remedy to encourage the use of herbal remedies such as "Calamus Draco" "dragons blood" to ensure incisional layers would heal without surgical site infections ${ }^{26}$.Calamus Draco was researched relatively recently and was discovered to have anti-microbial properties and was cicatrising in nature ${ }^{18}$.

Following wound healing, a considerable complication of surgery of the breast is haemorrhage and subsequent clotting as haematoma below the skin. As of medical practice today, careful use of compression, packing of the wound and haemostatic agents are used prophylactically and post-surgery as adjuncts to minimise the risks. This principle originates with exposition in Kitab Al Tasrif, where the prevention of such complications is of utmost importance; Abulcasis recommended the use of a topical 
corrosive agent called "zanjar"- copper acetate to erode the remaining fat and then dress the wound in a cotton compression dressing; this combination was found to have an anti-inflammatory and haemostatic activity $2,18,27$.

In the twenty-first century, the surgical management is limited to patients with treatment refractory gynaecomastia. It is expected nowadays for endocrinologists to employ the use of hormonal pharmacological therapy such as anti-oestrogen drugs (Tamoxifen) to aid the reduction in oestrogen driven breast growth ${ }^{28}$. Patients who do not respond to this treatment or with unidentified cause to breast growth will be taken to theatre. The surgical procedure that takes place nowadays has some similar objectives to that of Abulcasis' description-reduce the risk of haemorrhage and prevention of wound infection. However, surgery today requires forethought on important aims of surgery not previously considered, which significantly determine the success of the operation. The modern aims include aesthetic consideration of surgery, which has driven minimised incision lengths and is complemented by the use of liposuction particularly in less severe cases of gynaecomastia. The appealing features of the recovery was not considered by Abulcasis; he did not reference the aesthetics of the scars, shape of chest and excess skin resection. Due to this, it can be implied that there appeared to be complete emphasis on the functional nature of the surgery as opposed to the visual aspect ${ }^{2}$.

\section{Peri-operative Care}

As vital as it is to continually innovate operative procedures, it is concomitantly imperative to develop anaesthesia to reduce distress experienced by the patient. This was already considered by Abulcasis who went on to develop the anaesthetic sponge- the first inhalational anaesthesia ${ }^{29,30}$. The previous Greco-Roman practice of multiple doses of liquid anaesthetic solutions given during operations was phased out with this invention. The sponge was doused in aromatic compounds such as C-hyoscine and cannabis resin-hashish; one dose would penetrate the blood brain barrier's lipophilic layer and would persist for the entire operation $^{31}$. It would work by placing below the patient's nostrils and asking them to inhale. This inhalational anaesthesia gained notoriety for its effectiveness and became known in Europe as "Arabian nights"

In addition, Abulcasis pioneered the use of alcohol from wine as an aseptic technique, used to ensure surgical equipment remained untarnished for emergency operations ${ }^{34}$. Aseptic technique is vital to successful surgery, and surgery does not take place if this is compromised. Nowadays, as a consequence of the works of Pasteur's germ theory in the $19^{\text {th }}$ century, surgeons are now aware of preventing bacteria culturing on surgical equipment and hence instigating septic shock and surgical site infections ${ }^{35}$. Furthermore, the use of alcohol was seen when combined with rose oil to become a haemostatic agent; this composition would be added to basil icon ointment to prevent ulceration of the wound ${ }^{36}$.

Such was the importance of preventing haemorrhage, another tool used for this purpose was the cautery. Cauterisation is the practice of using thermal heat to prevent blood vessels bleeding and Abulcasis was a great advocate for the use of cauterisation. By dedicating an entire volume of Kitab Al Tasrif to its discussion, Abulcasis both exhibited his trust in the instrument but also ensured that it would be remembered for generations after his death.

During the eleventhcentury of the Middle Ages, phlebotomy and cauterisation were common treatments for ailments. Comparatively, nowadays operative cautery has been modified to use laser radiation rather than a pure thermal source. Nonetheless the theoretical array of uses and its effectivity and reputation have confirmed cauterisations prominence in current practice ${ }^{12,37}$. From nerve paralysis to tremors, use of cautery was a widespread conduit of healing. Abulcasis made significant advancements to include the use of cautery in the treatment of spinal pathologies discussed separately.Cauterisation was Abulcasis forte; specialising in bold inventions, designing multiple instruments and educating on the uses of such equipment. Each piece had its purpose, dependent on the function required, and Abulcasis maintained strong assertions of the curing power cautery presided. Confident of its effect, he quoted patient and surgeons experience and ensured his work was evidence based and credible for generations succeeding him.

Yet again,as was his nature, Abulcasis was not shy about departing from tradition and he openly challenges the previous opinions about cautery with strong authoritative tone, "where cauterisation should only be used in the spring as the ancients affirmed, I myself say cautery is suitable at all times" 18 . Moreover, he is disparaging about the use of caustic drugs over cautery and is logical in 
International Journal of Human and Health Sciences Vol. 04 No. 01 January'20

his explanation: pointing out that the neighbouring tissue is largely damaged by the general effect of caustic drugs unlike cautery ${ }^{34}$.

The idea that Abulcasis remained an educator beyond the material he was educating rings true, with evidence in the quote warning that some surgical procedures should not be attempted except "in those with good knowledge of anatomy of the limbs and the exits of the nerves that move the body". The quote is explaining the treatment of numbness of the limbs affected by spinal nerve roots and thus indicates the relative advances that took place to understand the function of the central nervous system (CNS) and its peripheral actions $^{17,18}$.

\section{Neurosurgery}

Along with numbness caused by the damage to the CNS, Abulcasis discussed in great detail the effects of spinal cord (CNS) injury and cervical vertebrae fractures. He was aware of the signs of a poor prognosis and said "When a fracture occurs in the bones of the neck and you want to know whether it will heal or not, then look and if you see both hands relaxed and numb and dead and he has no power to move or stretch or close them, and when you pinch them or prick them with a needle he does not notice it or feel any pain in them, you may know, as a general rule, that it will not mend, for he is doomed." 12,18 .

In the pathologies of the cranium, hydrocephalus was first described by the Ancient Greek physician Hippocrates as a disease where there was "water accumulating extra-axially" and this would take place in the skull. This was not known to be as a result of blockage to the complex ventricular system of the brain. The effect of the blockage would be increased cerebral pressureleading to enlarging and applying that extra pressure on the surrounding corte ${ }^{38-40}$.

In order to treat this devastating condition, Abulcasis devised an ingenuous method of surgically evacuating the intracranial fluid superficially. He recommended "decompressiontrepanation" which involved the use of a deep T-Shaped incision with a surgical scalpel expressly designed by Abulcasis to drain the superficial fluid $^{38,40}$. Because of the incomplete theory on cerebrospinal fluid (CSF)drainage, this hydrocephalus would have no doubt recurred in the patient in the future. It would take until Retzius and Keys in 1875 to determine the pathways of CSF drainage followed by Wernicke in the nineteenth century to treat the pathophysiological cause with a sterile ventricular puncture. Shunts have now transformed the treatment of hydrocephalus to pre-emptivelyavert recurrence ${ }^{39}$.

\section{Obstetric and Gynaecological Influence}

In the realm of maternal medicine, profound discoveries took place. The vaginal speculum was designed - specifically with a screwing mechanism and functionally movable blades in order to open the vagina and view the cervix clearly, to initiate procedures such as the extirpation of the dead foetus ${ }^{16,37}$. Contrastingly, when this work was first copied by some of the western illustrator's, copies were disseminated that had erroneously depicted the screwing mechanism as a decorative piece of artistry and this implies that function was not understood, and that the western world required much more guidance from the physicians of the Islamic world ${ }^{41,42}$.

By complete juxtaposition, the adoption of the lithotomy position and Walcher's position (first described in Kitab Al Tasrif) in the obstetric field took place in Europe with little guidance ${ }^{43}$. Until this day, an adaptation of Walcher's position is instigated during labour, by removing the lumbar lordosis of the spine and thrusting the pelvis forward, the pelvic brim is tilted forward, and legs lie on the edge of the bed unsupported. This is a key part of instrumental assisted vaginal deliveries because, the contractions engage the foetal head which then assists in traversing the birth canal ${ }^{44}$.

\section{Technological Innovations}

Such as the extent of Abulcasis' work, it would not do it justice to attempt to discuss all the technologies he devised. Amongst the most notable discoveries, Abulcasis wrote about pulsating and non-pulsating vessels - understanding some of the difference between arteries and veins. He innovated methods to stem haemorrhage of arteries with use of ligatures ${ }^{45}$. This detailed method was described in Kitab Al Tasrif almost six centuries prior to the reintroduction of their use by Ambroise Paré in Europe $^{10,46}$.

Much like the final brushstrokes of an artist or perchance completing an extensive piece of written work, the concluding steps define that piece. As a surgeon, Abulcasis was well aware of the importance of completing his work faultlessly; the difference between life and death. To improve the odds of life, he conceived the use of catgut for intestinal internal stitching. Catgut was discovered to be a naturally occurring suture that biodegraded with time and was not rejected by the body ${ }^{34,45,46}$. 


\section{Conclusion}

Overall, it is apparent that Abulcasis contributed greatly in a variety of operative and perioperative specialities; whether in conceiving innovative surgical instruments that have persisted centuries, theorising about new surgical approaches or emphasising evidence based approaches thus rejecting falsehoods of the ancient works.

As part of the blossoming centres of literature and science in Andalusia, his Kitab Al Tasrif revolutionised surgery at the time, his creativity and innovation resonate throughout his corpus. It is at this point, one is reminded that the discoveries and innovations elucidated upon in this piece occupy a metaphorical drop in the ocean of his entire work, a document comprising of thirty volumes crystallising all surgical knowledge of the time.

As a result, it is not surprising that KitabAl Tasrif became the basis of surgical curricula in European universities. Compiling the works of Greco-Roman physicians methodically and then correcting that which was false in an articulate manner ensured Abulcasis' left a significant scientific legacy.

Indeed, Abulcasis' work awakened the European interest in surgery and formed the backbone of surgical teaching for half a millennium. Translated and dispersed Kitab Al Tasrif undeniably aided improved patient's survivals posthumously but, perhaps it is the advice to budding surgeons his "sons" that offers the greatest message of all. It is a message of diligence, decorum and nonmaleficence, and states:"My sons, I would like you to know that there are two kinds of "working with our hands', that which is accompanied by safety and that which ends in disaster. So please seek dignity and conscientiousness for yourselves and assurance and safety for your patients." 11

\section{References:}

1. Elgood C. A Medical History of Persia and the Eastern Caliphate. Cambridge: Cambridge University Press. 2010.

2. Chavoushi S, Ghabili K, Kazemi A, Aslanabadi A, Babapour S, Ahmedli R et al. Surgery for Gynecomastia in the Islamic Golden Age: Al-Tasrif of Al-Zahrawi (936-1013 AD). ISRN Surgery. 2012;1-5.

3. Khan A. Avicenna (Ibn Sina): Muslim Physician and Philosopher of the Eleventh Century. New York: Rosen Publishing Group. 2006.

4. Adamson P. Interpreting Avicenna. Cambridge: Cambridge University Press. 2015.

5. Shoja M, Tubbs R, Loukas M, Khalili M, Alakbarli F, Cohen-Gadol A. Vasovagal syncope in the Canon of Avicenna: The first mention of carotid artery hypersensitivity. International Journal of Cardiology. 2009;134(3):297-301. Accessed 02.09.2019 Availablefrom: https://doi.org/10.1016/j. ijcard.2009.02.035
6. McGinnis J. Avicenna. 1st ed. Oxford: Oxford University Press. 2010.

7. Musallam B. Avicenna Medicine and Biology Encyclopaedia Iranica. Iranicaonline.org. 2017. Accessed 01.10.2017 Available from:http://www. iranicaonline.org/articles/avicenna-X

8. Gruner O. The Canon of Medicine of Avicenna. New York: AMS Pr.1973.

9. Saffari M. Avicenna's Canon of Medicine: A Look at Health, Public Health, and Environmental Sanitation. Archives of Iranian Medicine. 2012;15(12):785-789.

10. Cambra L. Abulcasis Al-Zahrawi, The Surgeon Of Al-Andalus. European Scientific Journal. University of Almeria. 2016.

11. Al-Benna S. Albucasis, a tenth-century scholar, physician and surgeon: His role in the history of plastic and reconstructive surgery. European Journal of Plastic Surgery. 2011;35(5):379-387.

12. Al-Rodhan N, Fox J. Al-Zahrawi and Arabian neurosurgery, 936-1013 ad. Surgical Neurology. 1986;26(1):92-95. 
International Journal of Human and Health Sciences Vol. 04 No. 01 January’20

13. Cosman M, Jones L. Handbook to life in the medieval world. New York: Facts On File; 2008.

14. Peterson M, Holbrook J, Hales D, Smith N, Staker L. Contributions of the History, Physical Examination, and Laboratory Investigation in Making Medical Diagnoses. Obstetrical \&GynecologicalSurvey.1992;47(10):711-712.

15. Gruppen L, Woolliscroft J,Wolf F. The contribution of different components of the clinical encounter in generating and eliminating diagnostic hypotheses. Research in Medical Education. 1988;27:242-247.

16. Hehmeyer I, Khan A. Islam's forgotten contributions to medical science. Canadian Medical Association Journal: Canada. 2007;176(10):1467-1468.

17. Nasr S, Michaud R. Islamic science. $1^{\text {st }}$ ed. Istanbul: InsanYayinlari; 1989.

18. Zahrāwī H, Lewis G, Spink M. Albucasis on surgery and instruments. London: The Wellcome Institute of the History of Medicine; 1973.

19. Sebastian A. A Dictionary of the History of Science. New York: Taylor \& Francis, 2001.

20. Hamarneh S. Albucasis on Surgery and Instruments. M. S. Spink , G. L. Lewis. Journal of Near Eastern Studies. 1976;35(4):293-294.

21. Rocca J. Galen on the brain: Anatomical Knowledge and Physiological Speculation in the Second Century Ad. 1st ed.Leiden:Brill. 2003.

22. Rahmani S, Turton P, Shaaban A, Dall B. Overview of Gynecomastia in the Modern Era and the Leeds Gynaecomastia Investigation Algorithm. The Breast Journal. 2011;17(3):246-255.

23. Diamandopoulos A, TheodorosK,Goudas P. Paulus Aegineta: The Pioneer of Plastic Surgery Evolution and Comparisons. Hospital Chronicles. 2007;2(2):83-88.

24. Papadakis M, Manios A, de Bree E, Trompoukis C, Tsiftsis D. Gynaecomastia and scrotal rhacosis: Two aesthetic surgical operations for men in Byzantine times. Journal of Plastic, Reconstructive \& Aesthetic Surgery. 2010;63(8):600-604.

25. Adams F. The seven books of Paulus Ægineta. London: Printed for the Sydenham Society. 1844.

26. 5. Gupta D, Bleakley B, Gupta R. Dragon's blood: Botany, chemistry and therapeutic uses. Journal of Ethnopharmacology. 2008;115(3):361-380.

27. Sharafkandi A. The Persian Translation of Qanoun Fi Al-Tibb. Tehran: Soroush Press. 2008.

28. National Institute for Health and Care Excellence. Familial breast cancer: classification, care and managing breast cancer and related risks in people with a family history of breast cancer CG 164 . London. 2013

29. Bhat A. Anesthesia Drugs in the Medieval Muslim Era. International Journal of Scientific \& Engineering
Research: Pulwama. 2013;4(3):1-9.

30. Moreno-Otero R.Abulcasis, the Father of Modern SurgeryMedical Archives: Madrid. 2013; 7(2):151.

31. Najjar J. From Anesthetic Sponge to Nonsinking Skull Perforator, Unitary Work Neurosurgery in the Ancient Arabic and Islamic World. World Neurosurgery: Homs, 2010;73(5):587-594.

32. Al-Fallouji M. Arabs were skilled in anaesthesia. BMJ: London, 1997;314(7087):1128-1128.

33. Jalal A.Abu Alkasem AL Zehrawi (Albucasis 936-1013). Child's Nervous System: Homs, 2009;26(7):857-859.

34. Nabri I. El Zahrawi (936-1013 AD), the father of operative surgery. The Annals of Royal college of Surgeons of England: London, 1983;65(2):132-134.

35. Reichman D, Greenberg J. Reducing Surgical Site Infections: A Review. Reviews in Obsteric and Gynaecology: United States,2009;2(4):212-221.

36. Saad M. Could Al-Zahrawi Be Considered a Biomedical Engineer?,Institute of Electrical and Electronics engineers: Egypt, 2016;7(2):56-67.

37. Savage-Smith E.The Practice of Surgery in Islamic Lands: Myth and Reality,Social History of Medicine: Oxford, 2000;13(2):307-321.

38. Turgut M. Surgical scalpel used in the treatment of infantile hydrocephalus by Al Zahrawi (9361013 a.d.). Child's Nervous System. 2008;25(9):10431044.

39. Hellier J. The Brain, the Nervous System, and Their Diseases.(Colorado: Greenwod Publishing Group. 2014

40. Aschoff A, Kremer P, Hashemi B, Kunze S. The scientific history of hydrocephalus and its treatment. Neurosurgical Review. 1999;22(2-3):67-93.

41. Loudon I. Western Medicine: An Illustrated History. Oxford University Press:Oxford and New York. 1997.

42. Jones P. Medieval medical miniatures. London: The British Library, in association with The Wellcome Institute for the History of Medicine. 1985.

43. Ahmed B. Abu Qasim Al- Zahrawi Albucasis The Father of the Surgery (936-1013), Tarrant County Medical Society: Texas. 2009

44. Collins S, Arulkumaran S, HayesK, Jackson S, Impey L, Oxford handbook of obstetrics and gynaecology, Oxford University Press: Oxford. 2008

45. Hamarneh S. A pharmaceutical view of Abulcasis al-Zahrawi in Moorish Spain. 1st ed. Leiden: Brill; 1963.

46. Arslan A, Benek S, Diramalı F, Diramalı M, Tonyalı F. Albucasis: Founder of Catgut. Acta Medica Anatolia. 2014;2(3):103. 